\title{
The Plural in the Singular, Cities and Disciplinary Batallions? - Interdisciplinary Approaches Facing Nowadays Environmental Challenges
}

\author{
Christian Sallenave \\ Bordeaux National Higher School of Architecture and Landscape Design, Talence 33400, France
}

\begin{abstract}
Towns' and cities' stories show their multidisciplinary richness and their complexity between professional skills and ways of life and residence of inhabitants by the analysis of the towns' changes. Through two protocols of research, during ten years from 2003 to 2012 and so on, of metropolitan changes in Bordeaux and travels in French and European cities, Christian Sallenave shows that: When everyone can write, tell and recognize his own story of town's changes, the cities know the best conditions for their sustainable development; Neither particular, nor general, but both in their specific dialectic; Neither panoptical and sovereign disciplines nor judgmental dopes, but both in their coming and goings and their “patriotic” property and register. The towns' stories are always written and marked in the same time in plural and singular, of arts, sciences and knowledge and pragmatic ways of life and residence.
\end{abstract}

Key words: Sustainable development, judgmental dopes, panoptical and sovereign disciplines, towns' stories, plural and singular arts, sciences, professional skills and pragmatic ways of life and residence.

\section{Introduction}

Cities, their architecture and urban landscapes have long been places where multiple trades, disciplines and specialties, multiple uses and representations compete and share differently the scene, in practice and in living memories

What happens when these urban actors must take into account, become in charge of, new orders, new interactions, new challenges, new disciplinary paradigms, such as those of sustainable development?

It appears that the multi and interdisciplinary approaches, to be operational to cope with present environmental challenges must be clearly established and be constantly questioned. Both in their respective disciplinary paradigms and in their tensions and articulations they have to be constantly renewed, in the

Corresponding author: Christian Sallenave, PhD, assistant professor, research fields: environment, architectural and urban design, identities and ways of life. E-mail: christiansallenave@yahoo.fr. framework of their socio-urban, disciplinary and professional boundaries.

At the risk to transform the necessary methodological reductions into ontological reductions: the urban morphologies would then be reducible, to meet the challenges of sustainable development, to new anthropological isolates of housing, new technical standards and new modes of governance.

However, it is widely recognized - by all jurisdictions of disciplinary inference [1] and bodies of legitimacy — that the changes implied by sustainable development policies are not reducible to technical standards or recommendations of social housing programs, public facilities or green one-family houses, or utopian demands and economic realism, constantly repeated in the advertisements or headlines of the mass media [2]. Since these changes are related to our identity, the way each of us dwells, adheres to certain goals and gets involved to reach them.

Therefore, multidisciplinary approaches must take into account, in their interdependencies and multiple interferences, the views of users and residents and 
those of programmers, scientists and designers as well as the constant interdisciplinary enrichments [3], functional diversity of uses and representations of the city, scientific as well as secular [4]. These transactions continually change, beyond their antagonist paradigms [5], their competitive cooperation [6], into alliances rather than in teamwork, into urban relay race rather than in disciplinary battle plans [7].

Certainly, "major projects" as they say, of "famous architects" and "famous clients" sometimes degrade the cities (Fig. 1), or skyscrapers standing at attention and large-scale mono-functional developments (Fig. 2), but nothing in these designs or constructions ensures any sustainable future other than that of an iconic landmark or arbitrary or state symbol, free from any transaction or democratic controversy.

\section{What is One Faced with and in What Dual Process does One Participate}

From the moment we refer the urban realizations to new planning requirements and sustainable development?

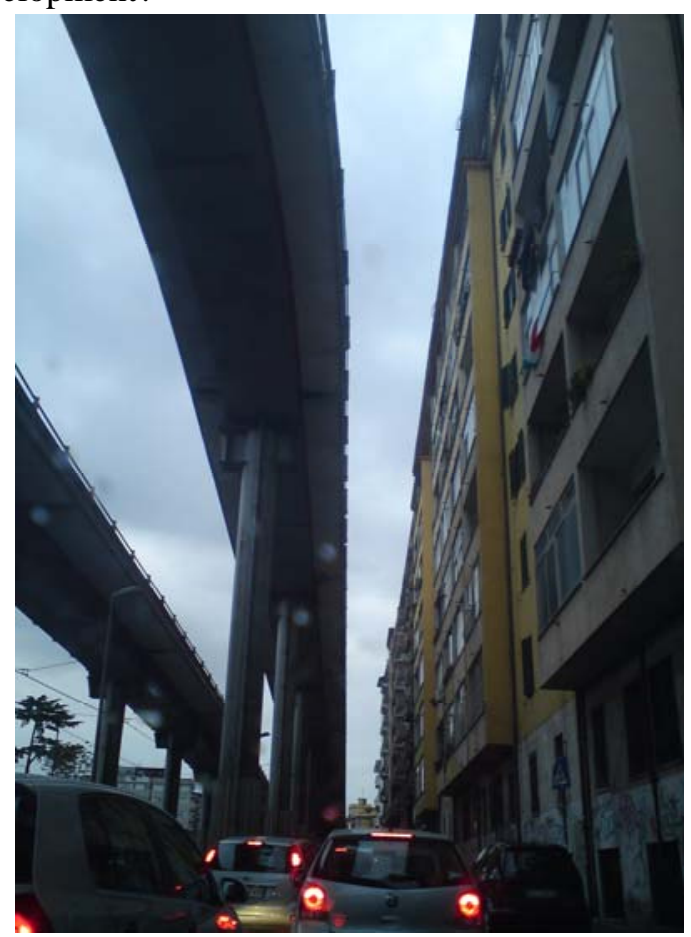

Fig. 1 Road overpass arbitrarily imposed on a neighborhood in Rome Photo Christian Sallenave.

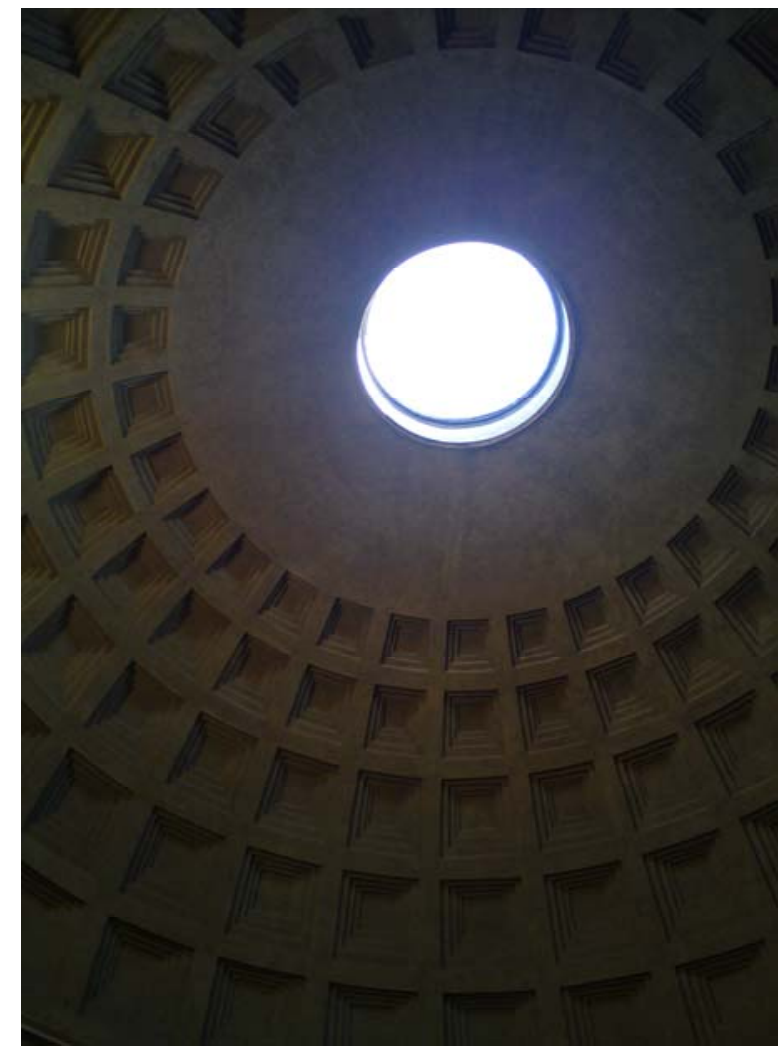

Fig. 2 The Pantheon in Rome, symbolic function which was converted urban cultural tourism Photo Christian Sallenave.

In Terms of Social and Scientific Legitimacy The experts stick to two types of discourse:

- The more or less utopian ideologists ask the actors to respect each other to make the working conditions of the team optimal, but in so doing they seem to preach in the desert. For, if, between them, the specialists confer together about their inter-paradigmatic translations, inside their own specialty each of them does "his/her job" and considers his/her point of view as "fundamental” and "essential”;

- The scientists, for their part, more or less pragmatic, make of each venture of cooperation and decision-making co-management, a new sociological, epistemological or anthropological isolate, conceptualized as "ambiguïté hybride” [8], “forum hybride" [9], "espace intersticiel”, and in doing this they reset a process of disciplinary patriotism. Each discipline appropriates the peripheral skills and integrate them in its own professional practice [10]. 


\section{The Plural in the Singular, Cities and Disciplinary Batallions? - Interdisciplinary Approaches Facing Environmental Challenges}

Both in multidisciplinary conferences and in each landscape, architectural and urban project, the interactional modus vivendi, implies that all the participants work together to a single definition of the situation [11].

In terms of scientific protocol and professional practice, especially for the sector of urban, architectural and landscape activities, the author notices since the end of the Second World War and especially since the first major oil crisis:

- Incessant transgressions of disciplinary boundaries which are constantly reaffirmed and reconfigured in sovereign and panoptic disciplines [12], supposedly hegemonic over all other specialties, reducing the others to a limited version of his own [13];

- Recurrent superpositions (rather than substitutions) of paradigms of conversion, recycling and protection of sanctuarized, even fossilized isolates. Any heritage not only protected (as from 1830, 1913 and 1930 in France) but also converted, reallocated and rearranged, like this or that abbey, abandoned factory or Hall, can be converted in an office building, or cultural tourism [14].

Like the UNESCO (United Nations Educational, Scientific and Cultural Organization) which has expanded and diversified its World Heritage List of Humanity includes now, beside protected architectural monuments and urban living landscapes, even an immaterial cultural heritage. Or the HDI (human development index), which incorporates a bigger and more fair diversity of criteria than only the economic criteria of the GDP (Gross Domestic Product).

This plural process which is constantly re-translated in the singular form is particularly illustrated in the multidisciplinary field of the arts, architecture and urban landscape:

- These "urban" arts are indeed more and more labeled in a plural, globalized form and at the same time in a singular form when linked to artistic creativity, the creative economy and the so-called singular and local works.

Outside the sanctuary of the museums, desecrated, democratized, the street arts and the performing arts, (rap is promoted to the "Victoires de la Musique", grafitty is exposed at the Grand Palais in Paris), become museum-ified "arts modestes" in Sète, or contemporary factual and media art events face the recognized Fine Arts. As Murakami's sculptures at Versailles, or the Antiques Fairs, which "also host the Contemporary Art”.

These desecrated arts gain in turn more and more acceptance as art in the full meaning of the word, subject to new disciplinary pretentions and claims, and new professional boundaries;

- The "everyday life" experts, residents and city users, are becoming more empowered and asked, since they are no longer seen as judgmental dopes [15], "idiots culturels" or agents unconscious of the processes of reproduction and change to which they participate.

Here the plural is effectively and consistently combined with and linked to the singular and at the same time to the public intimacies which are spread all over the world, standardized in the opinion polls, copied and pasted into Internet forums, blogs and Wikipedia.

As in the nineteenth century, the photography has democratized the "portrait". The family portraits, in their dining room competed with full-length portraits and paintings of the "masters of the world" in the Salons of the Louvre.

As in the time of Toulouse Lautrec, famous painter of exceptional posters, or the visionary art and industry of the cinema, the "cheese" poses in front of the anonymous click-clack of the popular Kodac and the Tattooed persons, and now the smile of the "people" on facebook, the art of exposing the body on a daily basis, exists already for a long time. The display - the "montre" in the words of Baudelaire or the show as the Americans say, is an art in itself and at the same time an 


\section{The Plural in the Singular, Cities and Disciplinary Batallions? — Interdisciplinary Approaches Facing Environmental Challenges}

industry throughout the towns and cities, and each time a completely new theater of singular and plural urban transformations.

For a long time these “popular arts” have left the streets to make an entrance into museums. For example, in France, the creation in the 1970s of the museums of “ordinary heritage” after the Arts and Traditions at the Palais de Chaillot in 1937.

And even longer the boundaries between the savant and the profane, between the recognized arts and the popular know-how or art for the people, are daily violated and continuously re-created, constantly changed. Claude Levi-Strauss [16] reminds us of the beautiful myths about the painters and sculptors of two neighboring tribes of Alaska. When in the myth of Tsimshian art is part of the daily life, that of the Tlingit gives art an independent kingdom.

\section{Everyone Finds a Job and Applies Oneself}

Not without difficulty, in the multidisciplinary back and forth and interlacing as shown by the so called participatory architecture, the governances at local, national and global levels, and different forms of participatory democracy, whether, since 20 years, on the local Agenda 21 or the UN summits of Rio, Kyoto, Copenhagen, Cancun or Durban.

But if recommendations propose, interactions and transactions [17], in repeatedly conflicts and solidarities between the different legitimacies [18], finally decide. Each (re)writes its own version of the history, integrates it according its own specific argumentation on behalf of its authentic experience on the side of the lay-users- and on the side of the scholars, artists or politicians on behalf of the scientific, artistic or political truth.

For ten years, part of the author's research are on urban forms, dwelling identities, "ways of living” and interdisciplinary approaches [19]. The author have noticed and assessed so many relative contextual truths [20].
In Bordeaux, the new tramway, opened in 2002, has been completed and win all the votes not because of any subtle compromise between the different areas of urban, political and scientific expertise, but because each of the actors and protagonists was able to translate it back into his own register of interest and discourse [21]:

- Policies have been able to re-translate it into terms of urban renewal and new metropolitan integration;

- Engineers-in terms of the World first use of the APS, Alimentation électrique Par le Sol (road surface power supply system by the soil) and not by catenary, in the historic center;

- Architects have retranslated its urban development and the designers its urban furniture in terms of a new visual identity;

- Sociologists have retranslated it in terms of new conditions of mobility of public transport;

- Environmentalists (scientists and activists) in terms of a new asset in energy saving and the fight against pollution and greenhouse gas emissions;

- The people of the whole city in terms of a new quality of life and renewed access to the heart of historical Bordeaux, certified World Heritage of the Unesco.

In another research, conducted by the GRECAU laboratory, I wanted to analyze the feelings, perceptions and representations of the users of public transport in their daily life, in relation to requirements of the sustainable city of the 21 century.

I asked the passengers, their ears and brain busy, as usual, by their MP3 or I pod, how they, during their daily commute, perceived, through the windows of the tram, the functional and social mix, the human and bio diversity and urban proximity advocated around the world in the name of sustainable development

What the author found was that the more your brains are occupied, your ears compressed and our bodies mobilized, the more you become indifferent to your perceptions and the more you need amplification in 
response to the redundancy of metropolitan sounds and images.

In contrast, without the MP3, during the return trip, all senses alert, the passengers proved more receptive to what they saw on the tram and outside on the streets, shop windows, cars and the city. They can differentiate again.

Neither particular, nor general, but both in their dialectic interaction, uses and representations, which are each time specific:

As much as the disciplinary panoptic cannot find what it seeks to induce, to dominate, focus and investigate, the amputation of the to-ing and fro-ing, in the public and private fields, risk to deprive the urban projects to express their different conflicting, competing urban scales and their diverse combined and reconciled perceptions.

It is important to preserve and take into account the polysensoriality of experienced situations [22] and the urban polysemy, and not reduce our feelings and our perceptions within the meaning of its dominant and unique panoptic perspective, to the point of confusing an urban plan and its uniform facades with the motherboard of a computer (Fig. 3). All are spared

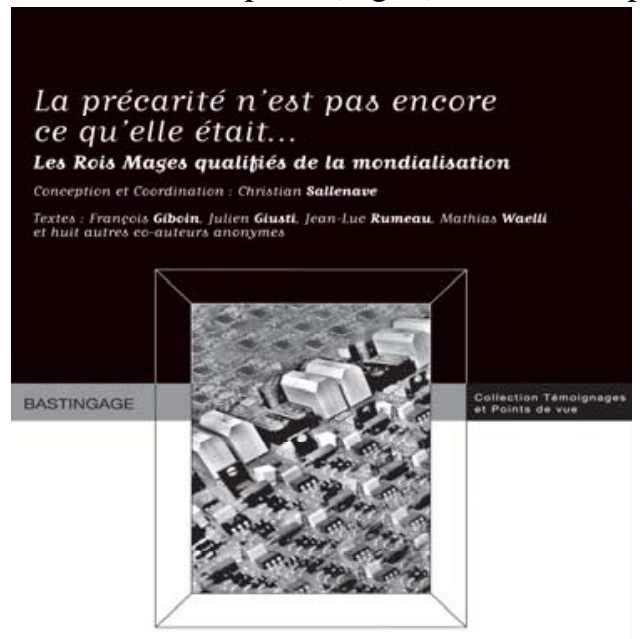

Fig. 3 Photo of a motherboard of computer, Cover of a book directed by C.Sallenave "Transient Employment is not what it used to be" photo F. Leclair.

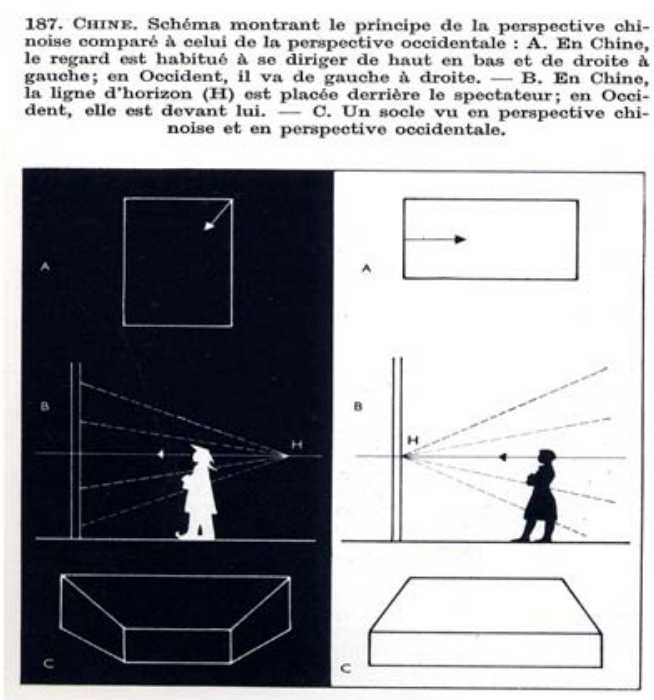

Fig. 4 In China the horizon is placed behind the spectator, in the West it is placed in front of the spectator.

from this when the history of the city is combined with the memory of its inhabitants.

Neither disciplinary panoptic nor judgmental dopes, but both the plural of the arts to build and the arts of living and dwelling, is thought of in the singular in the collaboration and in the urban relay races. Why are the perspectives of the Western Renaissance not concretized in the perspectives of Chinese arts (Fig. 4) [23] and in a true dialogue of civilizations? Why the secular art of making something new from something old does not also respond to the new academic questions posed by the Growth throughout the world?

\section{Conclusions}

Inhabited cities in the plural and/or disciplinary battalions in the singular?

The new ambivalence and potential sustainability of the planned change of civilization that all stakeholders of the city and architecture compose and improvise together, requires, when confronted with today's environmental challenges, to explore today for tomorrow.

Cities are multi interdisciplinary works. Their spaces are always lived, designed and programmed together, Their uses and representations as diverse as contrasting 
1640

\section{The Plural in the Singular, Cities and Disciplinary Batallions? - Interdisciplinary Approaches Facing Environmental Challenges}

require that: Their multiple and daily scenes should be as contested as shared to be effectively codified, through their respective professional and disciplinary translation;

Their polysemic tensions and articulations occur constantly between the common constraints of sustainable urban development and the translation that each memory could have written about it, that each body could have perceived and lived, that each version of the story could be specific and that the best of each discipline could offer and design. To know where you are, you have to look at the stars, but also know where you come from by memorizing the route you took [24].

Thus the plural can always be written in the singular (Fig. 5), and the improvisers can still pass for visionaries.

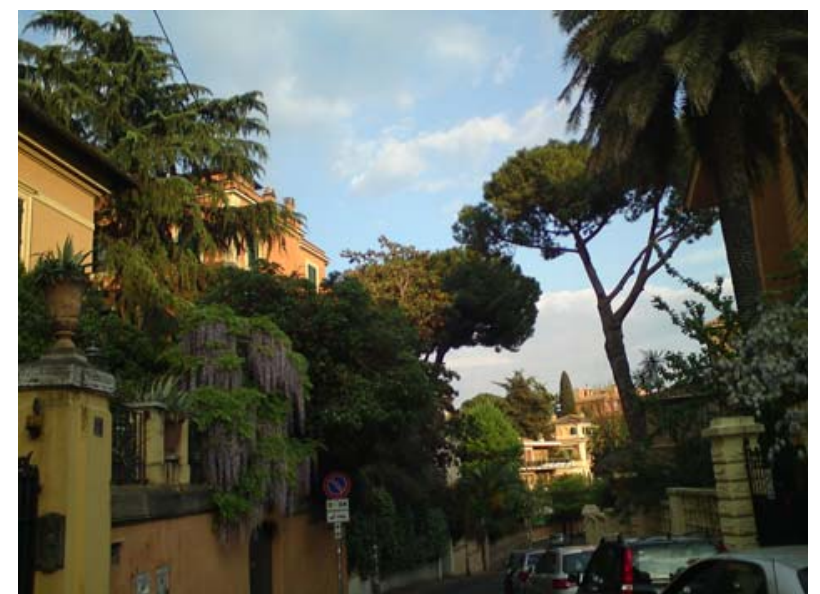

Fig. 5 View of Rome, a city where the plural and the singular are concretized for a long time, Photo Christian Sallenave.

\section{References}

[1] A. Abbott, The System of Professions, The Chicago University Press, Chicago, 1988.

[2] C. Sallenave, Sham Information and Training, Editions Frison-Roche, Paris, 1996. (in French)

[3] E. Goffman, The Presentation of Self in Everyday Life, Paris, 1973. (in French)

[4] C. Sallenave, Architectural Designs and Market Segmentations and Professional Groups in Elements for a Story in the New Towns, Manuscript University, Paris, 2004, pp. 183-198. (in French)
[5] C. Sallenave, Professionals and Users Professionals and Users Are Made to Hear the Intertwining between People and Professions of Urban (1960-2008) in the Annals of Urban Research, Paris, June 2008, pp. 28-37. (in French)

[6] T. Souami, The Sustainable Development Change the Universal of Town Planners in Annals of Urban Research, s/dir d'Anne Querrien, June 2008, pp. 19-27. (in French)

[7] B. Haumont, To be an architect in Europe, The Journal of Architectural Research, Métiers, Nov-Dec 1998, pp. 75-85. (in French)

[8] R. Venturi and D. Scott-Brown, Complexity and Contradiction in Architecture, New York, MOMA, 1966.

[9] B. Latour, Science in Action, How to Follow Scientists and Engineers through Society, Harvard University Press, 1987. (in French)

[10] C. Sallenave, Urbi and Bordeaux, Urban Decisions and Representations, Bordeaux, 2005.

[11] E. Goffman, The Presentation of Self in Everyday Life, Minuit, 1973. (in French)

[12] M. Foucault, Survey and Punish, Gallimard, 1975. (in French)

[13] A. Abbott, The System of Professions, The Chicago University Press, USA, 1988. (in French)

[14] C. Sallenave, Bordeaux-Unesco, The Issues of World Heritage, Ed. Bastingage, 2008. (in French)

[15] H. Garfinkel, Studies in Ethnomethodology, Cambridge Polity Press, 1984.

[16] C. Lévi-Strauss, Look, Listen and Read, Plon, 1993. (in French)

[17] C. Sallenave, Transient Employment is not What It Used to Be, Ed. Bastingage, 2006. (in French)

[18] M. Weber, Economy and Society 1920, Plon Pocket, 1995. (in French)

[19] C. Sallenave, P. Caumes and N. Miteneva, The Ferret, A Century of Architectures, Question of Ways of Life and Dwelling, Ed. Bastingage, 2011. (in French)

[20] P. Veyne, Did Greeks Believe in Their Myths, Le Seuil 2005. (in French)

[21] C. Sallenave, Settlement patterns and living Identities, in: Proceedings of the International Symposium, University of Bordeaux, Quebec, 2009.

[22] W. H. Ittelson and H. Proshansky, An Introduction to Environmental Psychology, Paris, 1974.

[23] J. Auboyer, The Esthetics of India and China in Art and Men, Larousse, 1958, pp. 65-67. (in French)

[24] W. Davis, The way finders with ancient wisdom matters in the modern world, House Ananci Press, Toronto, 2009. (in French) 